\title{
Psychopathological symptoms in children and adolescents diagnosed with autism spectrum disorders with comorbid epilepsy - case report
}

\author{
Objawy psychopatologiczne u dzieci i młodzieży z rozpoznaniem zaburzenia ze spektrum \\ autyzmu ze współwystępującą padaczką - opis przypadku
}

\section{Żaneta Brudkowska ${ }^{1}$ A,B,E,D, Katarzyna Jusiak ${ }^{2}{ }_{\mathrm{D}, \mathrm{F}, \mathrm{E}}$, Michał Próchnicki ${ }^{1,2}{ }_{\mathrm{D}, \mathrm{F}, \mathrm{E}}$, Beata Gołębiowska ${ }^{3} \mathrm{D}$, Justyna Morylowska - Topolska ${ }^{1}$ E, Ewelina Dziwota ${ }^{4}$, Paweł Pawełczak ${ }^{5,6}{ }_{F}$, Hanna Karakuła-Juchnowicz ${ }^{1,2}{ }_{D}$}

1. Department of Clinical Neuropsychiatry, Medical University of Lublin

2. Clinic of Psychiatry, Psychotherapy and Early Intervention ,Medical University of Lublin

3. Department of Neurology III Chair of Pediatrics, Medical University of Lublin.

4. II Department of Psychiatry and Psychiatric Rehabilitation, Medical University of Lublin

5. Health Care Unit, District Hospital in Sochaczew.

6. Health Center of Western Mazovia, Ltd.

\begin{abstract}
The number of diagnoses of Autism Spectrum Disorders (ASD) is on the rise, which encourages the search for their causes spurs researchers to study co-occurrence of ASD with other diseases and disorders. This study aims at highlighting the importance of the clinical problem of autism spectrum disorders and its comorbidity with epilepsy. This is one of the most common co-morbidities happening to children.

Regarding the psychopathological symptoms, it needs emphasizing that both in case of an isolated ASD and epilepsy itself, the accompanying psychiatric symptoms are confirmed. The research conducted so far also shows that in the course of epilepsy in the child / youth, mental health problems are often revealed, particularly depression and anxiety disorders. Episodes of depression and anxiety disorders are also mentioned as the most common comorbid psychopathological symptoms associated with ASD. An accurate and rapid diagnosis of epilepsy can improve the functioning of the child in the family environment and can improve communication skills. It is also important for the overall intellectual and psychological development. Making a correct diagnosis of the problem is equally crucial as choosing the right methods of medical and psychological care. Moreover, it determines the early use of adequate, safe and effective forms of treatment.
\end{abstract}

Keywords: ASD, epilepsy, psychopathological symptoms, mental disorders

\section{Streszczenie}

Częste rozpoznawanie zaburzeń ze spektrum autyzmu (ASD - Autism Spectrum Disorders)- skłania do intensyfikacji poszukiwania przyczyn jego powstawania oraz badania współwystępowania ASD z innymi chorobami i zaburzeniami. Praca ma na celu podkreślenie jak bardzo istotnym problemem klinicznym jest współwystępowanie zaburzeń ze spektrum autyzmu z padaczką, która jest jedną z najczęściej współwystępujących z ASD chorób w okresie dzieciństwa.

Skupiając się na objawach psychopatologicznych należy podkreślić, iż zarówno w izolowanym ASD jak i samej padaczce odnotowuje się objawy zaburzeń psychicznych towarzyszących. Z dotychczasowych badań wynika również, iż w przebiegu padaczki w tym dziecięcej/ młodzieńczej, często ujawniają się zaburzenia psychiczne w szczególności depresja i zaburzenia lękowe. Epizody depresji oraz zaburzenia lękowe wymieniane są również jako najczęściej współwystępujące objawy psychopatologiczne towarzyszące ASD. Trafna i szybka diagnoza epilepsji może poprawić funkcjonowanie dziecka w środowisku rodzinnym a także usprawnić umiejętności komunikacyjne; ma również duże znaczenie dla ogólnego rozwoju intelektualnego i psychologicznego. Dokonanie właściwej diagnozy problemu jest kluczowe w kwestii tak znaczącej jak wybór właściwej opieki medyczno - psychologicznej, ponadto warunkuje wczesne zastosowanie adekwatnych, bezpiecznych i efektywnych form terapeutycznych.

Słowa kluczowe: ASD, padaczka, objawy psychopatologiczne, zaburzenia psychiczne

\section{Introduction}

Over the last decades, there were numerous attempts to both systematize and categorize autism spectrum disorders [1,2]. In the current DSM - 5 classification
(Diagnostic and Statistical Manual of Mental Disorders) the previously highlighted Pervasive Development Disorders: autistic disorder, Asperger's disorder, children's disintegrative disorder, and pervasive developmental 
disorder, undiagnosed otherwise, are combined in one diagnostic domain - autism spectrum disorders (ASD ). The American Psychiatric Association encouraged the decision to change it, pointing to the fact that these four disorders represent a continuum rather in terms of severity (from mild to severe) than distinctly separate diagnostic units.

Using the recent American classification of mental disorders DSM-5, autism, also in the form described as a High-Functioning Autism (HFA), is classified in the category of autism spectrum disorders (ASD). According to the DSM-5, autism spectrum disorders are characterized by two core symptoms, i.e. communication / social interaction disorders and stereotyped, repetitive behaviors, interests and activities [3,4].

Although autism spectrum disorders have become subject to numerous research studies in recent decades, their etiology has yet to be clearly explained. At the moment, it is assumed that ASD are of pluricausal character, and among the factors etiologically significant primarily a combination of genetic and environmental factors are mentioned [5,6].

When analyzing the epidemiological data on ASD, some increase in the number of reported cases might be seen. The first studies on the autism prevalence in the UK were conducted in 1966. They showed the number of 4.5 per 10 000. A study conducted on American children in 1992 revealed; that the estimated number rose to 19 in $10.000[7,8]$. The latest epidemiological report created for WHO - Global Burden of Disease Study 2010 announces the prevalence of ASD as 1 in 132 people. In children aged less than 5 , autism is the most common cause of disability among all diseases and mental disorders [9].

The fact that autism spectrum disorders are frequently diagnosed tends to intensify the search for the causes of its development and the study of co-occurrence of ASD with other diseases and disorders.

This very study aims at describing a significant clinical problem - the comorbidity of ASD with epilepsy, which is one of the most common chronic diseases of the nervous system in the general population of children and adolescents. The prevalence rate is estimated to be approx. $0.5 \%$ [10]. On the other hand, it is estimated that some $30 \%$ of people diagnosed with ASD and related intellectual disabilities also suffer from seizures (in children with ASD in the intellectual norm it is $8 \%)[11,12,13]$.

\section{Psychopathological symptoms associated with autism spectrum disorders and epilepsy}

Regarding the psychopathological symptoms in the context of the described disorders it should be emphasized that both in an isolated ASD and epilepsy itself accompanying psychiatric symptoms are noted.

Recent studies indicate that children and adolescents diagnosed with ASD demonstrate psychiatric symp- toms to a greater extent than their healthy peers. Simonoff et al., using the study on the group of 112 people aged $10-14$ years reported that $70 \%$ of children diagnosed with autism spectrum disorder had at least one associated psychiatric disorder [14].

The research study by F. Salazar et al. showed that the most common ASD- comorbid psychiatric disorders among the studied group of 101 children aged 4.5-9.8 years were: generalized anxiety disorder (GAD) - 66.5\%, specific phobias - 52.7\%, and ADHD - 59.1\%. In addition, boys were more likely to suffer from an oppositionaldefiant disorder than girls. Higher IQ levels were also shown to affect anxiety disorders. Other studies have shown that intellectual disability of children with ASD is associated with more frequent revealing of psychopathological symptoms. In turn, night terror in the group of children correlated significantly with parental psychological distress $[15,16]$.

The issue of conceptualization itself poses a challenge for researchers and clinicians. It is unclear whether the symptoms and abnormalities seen in the behavior of children and adolescents with ASD can be understood in the traditional way, which is treating them as distinct mental disorders. The non-traditional way treats them as part of a clinical picture of autism spectrum disorders alone. The problem becomes even more complex when autistic disorders are accompanied by undiagnosed seizures [17].

The nature of the symptoms presented by the patients is dependent on the location of epileptic discharges. The symptoms may resemble a variety of psychopathological disorders. It is assumed that at the time of an epileptic seizure there are common characteristic disorders of mental functions, such as: short-term disturbances of perception, thinking, or affect. Psychiatric disorders manifesting in interictal periods are one of the most common problems of people with epilepsy. Due to a large diversity of the symptoms, these disorders pose diagnostic challenges to clinicians, while their prevalence indicates that they can be considered as a social problem [18].

Among interictal mental disorders, the most often mentioned include: dementia, psychosis and interictal affective disorder (mania or depression). The particular risk related to the risk of suicide is associated with interictal depression. On the other hand, ictal psychiatric disorders (occurring especially in patients with complex partial seizures located in the temporal lobe) are usually manifested by symptoms of anxiety, but also feelings of insecurity, irritability and depressed mood. Sometimes, they are the only symptoms of an epileptic seizure, hence they may pose difficulties in making a neurological diagnosis and delay the implementation of pharmacotherapy. A research study by Torta R. and R. Keller shows that in almost $60 \%$ of patients suffering from epilepsy of the temporal location report impaired cognitive and percep- 
tive functions, in particular such as visual, auditory, olfactory, tactile and sensory hallucinations, disorders of internal sensing, the illusions of sensing time or memory [19].

\section{Clinical case report}

A girl aged 12 was diagnosed with an autism spectrum disorder - F84.0 (the diagnosis was made when she was 4). The patient is currently being treated at the Clinic for People with Autism and participates in a multidisciplinary therapeutic - rehabilitation program. Given the current severity of symptoms, it can be stated that the patient suffers from so called "High-Functioning Autism" (HFA). It needs emphasizing, however, that at the earlier stages of condition's development, the symptoms were more pronounced.

The girl displays behaviors characteristic for autism spectrum disorders: impaired social interaction, sensory disorders, stereotyped patterns of behavior and interests, which significantly reduces the independent functioning of the child at home, school or in the community.

For a period of one year, the patient was under the care of a sensory integration disorders therapist due to the severity of the sensory hyperactivity disorder. For 9 years, due to the developmental disorders, she was receiving pedagogic, neurologopedic, psychological, psychiatric and neurological assistance. Past medical history in perinatal period includes an acute infectious disease in the mother during the first trimester of pregnancy. Regarding the early childhood development, speech delays were observed in the girl (both active and passive) and stereotypies, echolalia. .The child spoke her first words at the age of 3; when she was 4 , she started uttering simple sentences. Her psychomotor development was typical for patients with a diagnosis of autism spectrum disorder with regression periods, early onset (before the age of 3). The progress of motor development of the child proceeded correctly. General intellectual ability was at a mediocre level, but with visible disharmony.

Already at the pre-school age, the girl reported (verbalized) experiencing symptoms of acute anxiety, which were of the phase, episodic nature. Anxiety attacks were accompanied by aggressive behavior, explosive reactions of anger, agitation, social isolation, and withdrawal from peer contacts was noted. As a result, the girl from the age of 8 , has implemented compulsory education in a special school.

The first EEG examination conducted in a 3-year-old child revealed acceptable variations for the child's age. The EEG conducted at the age of four revealed some pattern of uncharacteristic anomalies. However, no neurological diagnosis was given. In turn, in the 11-year-old girl based on medical history and tests performed (EEG pattern incorrect) temporal lobe epilepsy was diagnosed.

An in-depth psychological diagnosis was conducted, due to the observed symptoms of anxiety and depression, which were also reported by the patient.. During psychological consultation, the girl often reported she felt anxious and insecure - reporting panic and admitted to having experienced unpleasant, visual and auditory hallucinations that lasted for a few minutes. The patient was critical about the hallucinations (no judgment realized). The collected information indicate that the first experience of hallucinations appeared approx. in a 10-year-old patient.

Currently, in the field of the development of emotional- social sphere, the girl has a pronounced tendency to dominate, often dysphoric tendencies (aggressive behavior towards relatives) and emotional lability occur. The patient often experiences intense anxiety accompanied by attacks of acute fear. This is a chief factor that strengthens her tendency to isolate herself from the society, meaning she is unwilling to make contact with others.

Regarding social relationships, the girl has not established any friendly contacts, does not integrate with the peer group, rarely ever starts conversation with colleagues at school. Overall, she is not interested in establishing any relationships. She has some difficulties understanding the emotions and adopting the perspective of others.

A detailed identification and measurement of the severity of the psychopathological symptoms were made using a clinical interview with the patient and her mother, as well as with the use of test methods: Wechsler Intelligence Scale WISC-R, BDI Beck Depression Inventory, and the State Trait Anxiety Inventory for Children - STAIC.

The results of the tests are as follows: BDI: 28 points. (According to patient's mother: 27 pts.), STAIC: Fear as Feature: 9 pts., Anxiety as a State: 10 pts., WISC-R II Full Scale: 108, II Verbal Scale: 102, II Wordless Scale: 113. In terms of measuring depressive symptoms, the patient achieved a high score (also, an assessment made by the mother of noted depression symptoms in her child). The results of the STAIC method also revealed very high levels of anxiety understood both as a feature of the emerging personality and conditioned by the situation.

The general development of intelligence in the patient currently is on an average level, with a slight predominance of executive over verbal intelligence. Systematization of presented by the patient psychopathological symptoms not included in the ASD criteria showed:

- Depressed mood,

- Emotional lability,

- High level of anxiety

- Underestimated self-esteem

- Strong tendencies to social isolation

- Periodic outbursts of aggression

- A constant sense of fatigue

- Thoughts of resignation 
- Suicidal thoughts

- Visual and auditory hallucinations in close connection with seizures and the accompanying strong fear.

The patient was treated with drug therapy (after the diagnosis of temporal lobe epilepsy): Levetiracetam 750mg 2x1; Fluoxetine 10mg 1x1; Haloperidol 0,75mg $2 \mathrm{x} 1$. Intensive, systematic psychotherapeutic effects were also implemented.

\section{Discussion}

Although there are numerous reports of the comorbidity of epilepsy and ASD, it is difficult to determine the risk factors for seizures in people with ASD. At the moment, researchers also argue about the nature of the relationship between ASD and epilepsy. [20,21].

Mental disorders in children diagnosed with both ASD and comorbid epilepsy pose both a diagnostic and therapeutic challenge. Despite that, a literature review indicates only one publication indirectly addressing this problem [22]. Findings of Turk et al. [22] indicate that children diagnosed with ASD and epilepsy experience great difficulties in social interaction, nonverbal communication, efficiency of motor function and self-service, when compared against children with a single diagnosis of ASD and a comparable level of intellectual development (without comorbid seizures).

Similar studies were conducted on the group of adults with intellectual disabilities. They have shown that people with ASD and comorbid epilepsy exhibited more frequent and stronger symptoms of anxiety disorders, behavioral disorders and social awareness and reveal pronounced difficulties in the ability to focus attention, when compared to patients with a single diagnosis of ASD or epilepsy, [23]. The studies referred to above suggest that people (including children) with comorbid epilepsy and ASD are more likely to demonstrate psychopathological symptoms compared to individuals with ASD without accompanying epilepsy or epilepsy without autism spectrum disorders.

The research carried out so far also shows that mental disorders tend to appear in the course of epilepsy in the child / youth. This pertains to depression and anxiety disorders. Episodes of depression and anxiety disorders are also mentioned as the most common comorbid psychopathological symptoms associated with ASD [24].

The emotional difficulties experienced by children with ASD are depression and severe anxiety. They require special attention of diagnosticians and researchers, as they affect the patients' quality of life, cause therapeutic difficulties and increase the risk of suicide [24,25].

An analysis of the research findings indicates the occurrence in the described patient obvious psychopathological symptoms comorbid with seizures (the diagnosis of temporal lobe epilepsy) and autism spectrum disorders. In many research works the frequency of epilepsy co-occurrence with ASD in children and adolescents, was confirmed [26, 27, 28]. There is also a huge number of reports on the presence of mental disorders in both isolated epilepsy and in ASD itself [29,30, 31, 32].

Despite that, a few studies focused on the subject of co-occurrence of psychopathological symptoms in people with dual diagnosis: autism spectrum disorder and epilepsy were published.

In case of children and adolescents, comorbidity of ASD symptoms with other psychopathological symptoms may be associated with diagnostic difficulties resulting from symptoms overlap, misinterpretation of the causes of problematic reactions and behaviors of the child. The key problem is related to the diagnostic understanding of the nature / cause of emerging psychopathological symptoms more common among children with ASD than in the general population of children and adolescents. It needs emphasizing that psychiatric symptoms may be the only demonstration of seizure disorders in epilepsy [18]. An accurate and rapid diagnosis of epilepsy can improve the functioning of the child in the family environment and can improve their communication skills; it is also important for the overall intellectual and psychological development. Providing a correct diagnosis is crucial for choosing the proper medico - psychological care; moreover, it determines the use of adequate, safe and effective forms of treatment.

The case of a patient described in this study included a diagnosis of temporal lobe epilepsy and ASD, revealing psychopathological symptoms. It emphasizes the need to address the problem of co-occurrence of these disorders, and should encourage and inspire discussion on the issues of the complexity of the psychopathological symptoms in children and adolescents diagnosed with cooccurring autism spectrum disorder and epilepsy.

This very case points to the need for multidisciplinary diagnostic and therapeutic cooperation with regard to patients with complex clinical picture and mixed etiology of disorders [33].

It might be concluded that patients with a diagnosis of autism spectrum disorder are prone to additional diseases and disorders, the symptoms of which, often coinciding with each other, may complicate and prolong the diagnostic process. It is a disadvantage, regarding the context, the effectiveness of the therapy and its impact on prognosis - which legitimizes this and similar works. Accurate and rapid diagnosis of epilepsy can improve functioning in the family environment and can improve the communication skills of the child. 


\section{Wstęp}

Na przestrzeni ostatnich dekad starano się usystematyzować i dokonać kategoryzacji zaburzeń ze spektrum autyzmu [1,2]. W aktualnej klasyfikacji DSM - 5 (Diagnostic and Statistical Manual of Mental Disorders połączono dotychczas wyróżniane całościowe zaburzenia rozwoju: zaburzenie autystyczne, zaburzenie Aspergera, dziecięce zaburzenie dezintegracyjne oraz całościowe zaburzenia rozwojowe, niezdiagnozowane inaczej, w jedną domenę diagnostyczną - zaburzenia ze spektrum autyzmu (ASD). Decyzję o zmianie American Psychiatric Association umotywowało tym, iż wyżej wymienione cztery zaburzenia stanowią raczej kontinuum pod względem nasilenia objawów (od łagodnych do ciężkich) niż wyraźnie odrębne jednostki diagnostyczne.

Opierając się więc na najnowszej amerykańskiej klasyfikacji zaburzeń psychicznych DSM-5 - autyzm, również ten opisywany jako „wysokofunkcjonujący” (High-Functioning Autism - HFA) ujmowany jest w kategorii zaburzeń ze spektrum autyzmu (ASD). Zgodnie z kryteriami DSM-5 zaburzenia ze spektrum autyzmu charakteryzują się występowaniem dwóch osiowych objawów tj. zaburzeń komunikacji / interakcji społecznych oraz stereotypowych, powtarzalnych zachowań, zainteresowań i aktywności [3,4].

Pomimo, iż zaburzenia ze spektrum autyzmu na przestrzeni ostatnich dziesięcioleci stały się przedmiotem wielu badań i dociekań naukowców, do dzisiaj nie udało się jednoznacznie wyjaśnić ich etiologii. Aktualnie przyjmuje się, iż ASD determinowane są wieloprzyczynowo, a wśród czynników etiologicznie znaczących wymienia się głównie kombinację czynników genetycznych i środowiskowych [5,6].

Analizując dane epidemiologiczne dotyczące ASD można zauważyć wzrost raportowanych zachorowań. W pierwszych badaniach dotyczących częstości występowania autyzmu w Wielkiej Brytanii w 1966 roku podawano liczbę 4.5 na 10000 , w populacji dzieci amerykańskich w 1992 szacowana liczba wzrosła do 19 na 10,000 [7,8]. Najnowszy raport epidemiologiczny utworzony dla WHO Global Burden of Disease Study 2010 informuje o częstości występowania ASD 1 na 132 osoby. U dzieci poniżej 5 roku życia autyzm jest najczęstszą przyczyną niepełnosprawności wśród wszystkich chorób i zaburzeń psychicznych [9].

Częste rozpoznawanie zaburzeń ze spektrum autyzmu skłania do intensyfikacji poszukiwania przyczyn jego powstawania oraz badania współwystępowania ASD z innymi chorobami i zaburzeniami.

Niniejsza praca ma na celu przedstawienie istotnego problemu klinicznego jakim jest współwystępowanie ASD z padaczką, która jest jedną z najczęściej występujących przewlekłych chorób układu nerwowego w ogólnej populacji dzieci i młodzieży. Wskaźnik jej rozpowszechnienia ocenia się na ok. 0,5 \% [10]. Z kolei szacuje się, iż
30\% osób z rozpoznaniem ASD i towarzyszącą niepełnosprawnością intelektualną cierpi również z powodu napadów padaczkowych ( $\mathrm{w}$ grupie dzieci z ASD w normie intelektualnej jest to $8 \%$ ) $[11,12,13]$.

\section{Objawy psychopatologiczne towarzyszące zaburze- niom ze spektrum autyzmu i padaczce}

Skupiając się na objawach psychopatologicznych w kontekście omawianych zaburzeń należy podkreślić, iż zarówno w izolowanym ASD jak i samej padaczce odnotowuje się objawy zaburzeń psychicznych towarzyszących.

Ostatnie badania wskazują, iż dzieci i młodzież z diagnozą ASD wykazują w większym stopniu niż ich zdrowi rówieśnicy objawy zaburzeń psychicznych. Simonoff i wsp. na podstawie przeprowadzonego badania w grupie 112 osób w wieku od 10 - 14 lat donoszą, iż $70 \%$ badanych dzieci z rozpoznaniem zaburzeń ze spektrum autyzmu miało przynajmniej jedno towarzyszące zaburzenie psychiczne [14] .

Badania Salazar F. i współpracowników wykazały, iż do najbardziej powszechnych współwystępujących z ASD zaburzeń psychicznych wśród badanej grupy 101 dzieci w wieku 4.5-9.8 lat należały: zaburzenia lękowe uogólnione (generalized anxiety disorder - GAD) - $66.5 \%$, fobie specyficzne - $52.7 \%$ oraz ADHD - $59.1 \%$. Dodatkowo zaobserwowano częstsze występowanie zaburzenia opozycyjnobuntowniczego u badanych chłopców w porównaniu do dziewcząt. Wyższy poziom zdolności intelektualnych (IQ) wiązał się również z silniejszymi tendencjami do przejawiania zaburzeń lękowych. W innych badaniach wykazano, że niepełnosprawność intelektualna dzieci z ASD wiązała się również z częstszym ujawnianiem objawów psychopatologicznych. Z kolei lęki nocne ujawniane w badanej grupie dzieci korelowały znacznie z przeżywaniem dystresu psychologicznego przez rodziców $[15,16]$

Wyzwaniem dla badaczy i klinicystów jest również sam problem konceptualizacji, wydaje się bowiem niejasne czy symptomy i nieprawidłowości widoczne w zachowaniu dzieci i młodzieży z ASD można rozumieć jako tradycyjnie definiowane, odrębne zaburzenia psychiczne czy raczej powinno się je traktować jako wpisujące się w obraz kliniczny samych zaburzeń ze spektrum autyzmu. Problem staje się jeszcze bardziej skomplikowany, gdy zaburzeniom autystycznym towarzyszą niezdiagnozowane napady padaczkowe [17].

W zależności od lokalizacji wyładowań padaczkowych, prezentowane przez pacjentów objawy mogą przypominać różne symptomy psychopatologiczne. Uznaje się, iż w czasie napadu padaczkowego powszechne są typowe zaburzenia funkcji psychicznych np.: krótkotrwałe zaburzenia postrzegania, myślenia lub afektu. Zaburzenia psychiczne ujawniające się w okresach międzynapadowych są jednym z najczęstszych problemów osób chorych 
na padaczkę. Ze względu na duże zróżnicowanie objawów sprawiają one klinicystom trudności diagnostyczne, z kolei ich rozpowszechnienie wskazuje, iż można je traktować jako problem społeczny [18]. Wśród międzynapadowych zaburzeń psychicznych najczęściej wymienia się: zespół otępienny, psychozy międzynapadowe i zaburzenia afektu (mania lub depresja). Szczególne niebezpieczeństwo, bo związane z ryzykiem samobójstwa, wiąże się $\mathrm{z}$ depresją międzynapadową. Z kolei śródnapadowe zaburzenia psychiczne (występujące szczególnie u pacjentów z napadami częściowymi złożonymi zlokalizowanymi w płacie skroniowym) najczęściej ujawniają się w formie objawów lęku, ale także uczucia niepokoju, niepewności, drażliwość i obniżonego nastroju. Niekiedy są one jedynym objawem napadu padaczkowego, mogą zatem stanowić znaczne utrudnienia w postawieniu neurologicznej diagnozy oraz opóźniać wdrożenie farmakoterapii. Z pracy badawczej Torta R. i Keller R. wynika, iż u niemal $60 \%$ chorych na padaczkę o lokalizacji skroniowej występują zaburzenia poznawcze i postrzegania, szczególnie takie jak: omamy wzrokowe, słuchowe, węchowe, dotykowe i czucia wewnętrznego, złudzenia poczucia czasu lub pamięci [19].

\section{Opis przypadku klinicznego}

12-letnia dziewczynka z rozpoznaniem zaburzeń ze spektrum autyzmu - F84.0 (diagnozę postawiono w 4 roku życia dziecka). Pacjentka aktualnie jest otoczona wielospecjalistyczną opieką w ramach Poradni dla Osób z Autyzmem oraz uczestniczy w programie terapeutyczno - rehabilitacyjnym. Uwzględniając aktualny stopień nasilenia objawów, można stwierdzić, że u pacjentki występuje tzw. „autyzm wysokofunkcjonujący” (HFA -HighFunctioning Autism). Należy podkreślić jednak, iż na wcześniejszych etapach rozwoju dziecka objawy autyzmu były wyraźniejsze.

Dziewczynka prezentuje cechy charakterystyczne zaburzeń ze spektrum autyzmu: zaburzenia w zakresie interakcji społecznych, zaburzenia sensoryczne, stereotypowe wzorce zachowania i zainteresowań; co znacznie ogranicza samodzielne funkcjonowanie dziecka w środowisku domowym, szkolnym oraz społecznym.

Od roku pacjentka jest pod opieką terapeuty zaburzeń integracji sensorycznej z uwagi na nasilenie zaburzeń o charakterze hiperreaktywności sensorycznej.

Od 9 lat pozostaje pod opieką pedagogiczną, neurologopedyczną, psychologiczną, psychiatryczną oraz neurologiczną z powodu zaburzeń rozwojowych. W wywiadzie obciążenie okołoporodowe pod postacią ostrej choroby zakaźnej u matki $\mathrm{w}$ okresie I trymestru ciąży. W zakresie rozwoju wczesnodziecięcego u dziewczynki obserwowano opóźnienia rozwoju mowy (czynnej i biernej) oraz stereotypie, echolalie. Dziecko pierwsze słowa wypowiadało po 3 roku życia, w 4 roku życia zaczęło budować proste zdania. Rozwój psychoruchowy kształtował się jako typowy dla pacjentów z rozpoznaniem zaburzeń ze spektrum autyzmu, z okresami regresji, wczesnym początkiem (przed 3 rokiem życia). Dynamika rozwoju motorycznego dziecka przebiegała prawidłowo. Ogólne zdolności intelektualne kształtowały się na poziomie przeciętnym, lecz widoczną dysharmonią.

Już w okresie przedszkolnym dziewczynka zgłaszała (werbalizowała) doświadczanie objawów silnego lęku, które miały charakter fazowy, epizodyczny. Napadom lęku towarzyszyły zachowania agresywne, wybuchowe reakcje złości, pobudzenie psychoruchowe, zaznaczały się tendencje do izolacji społecznej, wycofywania się z kontaktów rówieśniczych. W konsekwencji dziewczynka od 8 roku życia realizuje obowiązek edukacyjny w szkole specjalnej.

Pierwsze badanie EEG wykonane w 3 roku życia dziecka wskazywało na zapis w granicach dopuszczalnej zmienności dla wieku dziecka. W wieku 4 lat w zapisie EEG widoczne bliżej niecharakterystyczne nieprawidłowości - nie postawiono jednak neurologicznego rozpoznania. Z kolei w 11 roku życia dziewczynki na podstawie wywiadu, obserwacji oraz wykonanych badań (EEG zapis nieprawidłowy) rozpoznano u pacjentki padaczkę skroniową.

W okresie ostatnich trzech miesięcy z powodu obserwowanych i zgłaszanych przez badaną nasilonych objawów lękowych i depresyjnych przeprowadzono pogłębioną diagnostykę psychologiczną. W czasie konsultacji psychologicznych dziewczynka często zgłaszała występowanie uczucia niepokoju, niepewności, panicznego lęku oraz doświadczania nieprzyjemnych, trwających do kilku minut omamów wzrokowych i słuchowych. Wobec halucynacji pacjentka zachowywała krytycyzm (brak sądu realizującego). Z zebranych informacji wynika, iż pierwsze doświadczenia halucynacji pojawiły się ok. 10 roku życia pacjentki.

Obecnie w zakresie rozwoju sfery emocjonalno społecznej dziewczynka wykazuje wyraźne skłonności do dominacji, często tendencje dysforyczne (zdarzają się zachowania agresywne wobec bliskich) oraz labilność emocjonalną. Pacjentka często doświadcza intensywnego niepokoju, towarzyszą mu napady silnego lęku, który jest głównym czynnikiem wzmacniającym tendencje do izolacji społecznej, niechęci dziecka do podejmowania kontaktów z innymi.

W zakresie relacji społecznych dziewczynka nie nawiązała przyjaźni, nie integruje się z grupą rówieśniczą, $\mathrm{z}$ trudem podejmuje konwersację $\mathrm{z}$ kolegami i koleżankami w szkole (nie jest zainteresowana nawiązywaniem relacji). Ujawnia pewne trudności w zakresie rozumienia emocji oraz przyjmowania perspektywy innych.

Szczegółowej identyfikacji i pomiaru nasilenia występujących objawów psychopatologicznych dokonano przy pomocy wywiadu klinicznego z pacjentką oraz jej matką, a także $\mathrm{z}$ zastosowaniem metod testo- 
wych: Skali Inteligencji Wechslera WISC-R, Kwestionariusza Depresji BDI Becka, Inwentarza Stanu i Cechy Lęku dla Dzieci - STAIC.

Wyniki przeprowadzonych badań: BDI: 28 pkt. (w ocenie matki pacjentki: 27 pkt.), STAIC: Lęk jako Cecha: 9 pkt., Lęk jako Stan: 10 pkt., WISC-R: II Skala Pełna: 108, II Skala Słowna: 102, II Skala Bezsłowna: 113. W zakresie pomiaru objawów depresji badana osiągnęła wysoki wynik (zarówno w dokonanej przez matkę ocenie zauważanych objawów depresyjności u dziecka). Wyniki badania metodą STAIC ujawniły również bardzo wysoki poziom lęku rozumianego zarówno jako cecha kształtującej się osobowości jak i uwarunkowanego sytuacyjnie. Ogólny rozwój inteligencji pacjentki aktualnie kształtuje się na poziomie przeciętnym, $\mathrm{z}$ nieznaczną przewagą inteligencji wykonawczej nad słowną.

Systematyzacja prezentowanych przez badaną pacjentkę objawów psychopatologicznych nieujętych w kryteriach ASD wykazała:

- obniżony nastrój,

- labilność emocjonalną,

- wysoki poziom lęku

- zaniżoną samoocena

- silne tendencje do izolacji społecznej

- okresowe wybuchy agresji

- stałe poczucie zmęczenia

- myśli rezygnacyjne

- myśli samobójcze

- omamy wzrokowe i słuchowe w ścisłym związku z napadami padaczkowymi oraz towarzyszącym silnym lękiem

U pacjentki zastosowano farmakoterapię (od momentu postawienia diagnozy padaczki skroniowej): lewetiracetam $750 \mathrm{mg} 2 \times 1$; fluoksetyna $10 \mathrm{mg} 1 \times 1$; haloperidol 0,75mg 2x1. Wdrożono również intensywne, systematyczne oddziaływania psychoterapeutyczne.

\section{Dyskusja}

Pomimo, iż doniesienia o współwystępowaniu napadów padaczkowych oraz ASD są dość częste, trudno jest jednoznacznie określić czynniki ryzyka pojawienia się napadów padaczkowych u osób z ASD. Aktualnie wśród badaczy toczy się również spór o naturę związku pomiędzy ASD a padaczką [20,21].

Szczególnym wyzwaniem diagnostycznym i terapeutycznym stają się zaburzenia psychiczne, w grupie dzieci z rozpoznaniem zarówno ASD oraz współtowarzyszącej padaczki. Pomimo tego przegląd literatury wskazał tylko jedną publikację pośrednio dotykającą tego problemu [22]. Rezultaty przeprowadzonego badania przez Turk i wsp. [22] wskazują, iż dzieci z rozpoznaniem ASD oraz padaczki prezentują większe trudności w zakresie społecznych interakcji, niewerbalnej komunikacji, sprawności funkcji motorycznych oraz samoobsługi w porównaniu do dzieci z pojedynczą diagnozą ASD i porównywalnym poziomem rozwoju intelektualnego (bez współwystępujących napadów padaczkowych). Podobne badania zostały przeprowadzone w grupie osób dorosłych z niepełnosprawnością intelektualną. Wynika z nich, iż osoby z towarzyszącym ASD i padaczką w porównaniu do osób z pojedynczym rozpoznaniem ASD lub padaczki przejawiały częstsze i silniejsze objawy zaburzeń lękowych, zaburzeń zachowania i umiejętności społecznych oraz ujawniały wyraźniejsze trudności w zakresie zdolności do koncentrowania uwagi [23]. Powyżej przytoczone badania sugerują, iż osoby (również dzieci) z współwystępującym ASD oraz padaczką wykazują większą liczbę objawów psychopatologicznych w porównaniu do osób z ASD bez towarzyszącej padaczki lub osób z padaczką lecz bez zaburzeń ze spektrum autyzmu.

Z dotychczasowych badań wynika również, iż w przebiegu padaczki w tym dziecięcej/ młodzieńczej, często ujawniają się zaburzenia psychiczne w szczególności depresja i zaburzenia lękowe. Epizody depresji oraz zaburzenia lękowe wymieniane są również jako najczęściej współwystępujące objawy psychopatologiczne towarzyszące ASD [24].

Pojawiające się trudności emocjonalne w postaci stanów depresyjnych oraz przeżywania nasilonego lęku u dzieci z ASD wymagają szczególnej uwagi diagnostów i badaczy, gdyż wiążą się z istotnym obniżeniem jakości życia pacjentów, trudnościami terapeutycznymi oraz niosą ze sobą zwiększone ryzyko samobójcze $[24,25]$.

Analiza wyników przeprowadzonych badań wskazuje na występowanie u opisywanej przez nas pacjentki wyraźnych objawów psychopatologicznych współwystępujących z napadami padaczkowymi (rozpoznanie padaczki skroniowej) oraz zaburzeniami ze spektrum autyzmu. W wielu pracach badawczych potwierdzano częstość współwystępowania padaczki u dzieci i młodzieży z ASD $[26,27,28]$. Bogaty jest również zbiór doniesień dotyczących obecności zaburzeń psychicznych zarówno w izolowanej padaczce jak i samym ASD [29,30, 31, 32].

Pomimo tego powstało niewiele prac poruszających tematykę współwystępowania objawów psychopatologicznych u osób z podwójnym rozpoznaniem: zaburzeń ze spektrum autyzmu oraz padaczki.

W przypadku dzieci i młodzieży współwystępowanie objawów ASD z innymi objawami psychopatologicznymi może wiązać się z trudnościami diagnostycznymi wynikającymi z nakładania się objawów, błędnej interpretacji przyczyn problematycznych reakcji i zachowań dziecka. Główna trudność diagnostyczna dotyczy rozumienia natury/przyczyny pojawiających się objawów psychopatologicznych bardziej powszechnych wśród dzieci z ASD niż w ogólnej populacji dzieci i młodzieży. 
Należy podkreślić, iż objawy zaburzeń psychicznych mogą być jedyną demonstracją zaburzeń napadowych w padaczce [18]. Trafna i szybka diagnoza epilepsji może poprawić funkcjonowanie dziecka w środowisku rodzinnym a także usprawnić umiejętności komunikacyjne; ma również duże znaczenie dla ogólnego rozwoju intelektualnego i psychologicznego. Dokonanie właściwej diagnozy problemu jest kluczowe w kwestii tak znaczącej jak wybór właściwej opieki medyczno - psychologicznej, ponadto warunkuje zastosowanie adekwatnych, bezpiecznych i efektywnych form terapeutycznych.

Opisywany w niniejszej pracy przypadek pacjentki z rozpoznaniem padaczki skroniowej oraz ASD ujawniającej objawy psychopatologiczne podkreśla konieczność pochylenia się nad problemem współwystępowania wymienionych zaburzeń, powinien zachęcić i inspirować do dyskusji nad problematyką złożoności objawów psychopatologicznych u dzieci i młodzieży z rozpoznaniem współwystępujących zaburzeń ze spektrum autyzmu oraz padaczki.

Przedstawiony przypadek wskazuje na konieczność zastosowania multidyscyplinarnej współpracy diagnostyczno-terapeutycznej wobec pacjentów o złożonym obrazie klinicznym i mieszanej etiologii zaburzeń [33].

Podsumowując można stwierdzić, iż pacjenci z rozpoznaniem zaburzeń ze spektrum autyzmu wykazują skłonność do dodatkowych zaburzeń i chorób, których objawy niejednokrotnie pokrywając się ze sobą mogą komplikować i wydłużać proces diagnostyczny co jest niekorzystne $\mathrm{w}$ kontekście efektywności terapii i jej wpływu na rokowanie - co legitymizuje tą i jej podobne prace. Trafna i szybka diagnoza epilepsji może poprawić funkcjonowanie $w$ środowisku rodzinnym a także usprawnić umiejętności komunikacyjne dziecka.

\section{References:}

1. Charman T., Jones C., Pickles A., Simonoff E., Baird G., Happé F. Defining the cognitive phenotype of autism. Brain Res, 2011; 1380:10-21.

2. Georgiades S., Szatmari P., Boyle M., Hanna S., Duku E., Zwaigenbaum L., et al. Investigating phenotypic heterogeneity in children with autism spectrum disorder : a factor mixture modeling approach. J Child Psychol Psychiatry, 2013; 54:206-215.

3. Grzadzinski R., Huerta M., Lord C. DSM-5 and autism spectrum disorders (ASDs): an opportunity for identifying ASD subtypes. Mol. Autism, 2013; 4: 12 .

4. DSM-5. American Psychiatric Association; http://www.dsm5.org /Pages/Defaultaspx [dostęp:15.07.2014],

5. Won H., Mah W., Kim E. Autism spectrum disorder causes, mechanisms, and treatments: focus on neuronal synapses. Front Mol Neurosci, 2013; 05(6): 19.

6. Hallmayer J., Cleveland S., Torres A., Phillips J., Cohen B., Torigoe T et al. Genetic heritability and shared environmental factors among twin pairs with autism. Arch. Gen. Psychiatry, 2011; 68: 1095-102.

7. Lotter V. Epidemiology of autistic conditions in young children: I. Prevalence. Soc. Psychiatry, 1966; 1: 124-137.

8. Autism and Developmental Disabilities Monitoring Network Surveillance Year 2008 Principal Investigators Centers for Disease Control and Prevention. Prevalence of autism spectrum disorders-Autism and Developmental Disabilities Monitoring Network, 14 sites, United States 2008. Surveill. Summ., 2012; 61:1-19.

9. Baxter A., Brugha T., Erskine H., Scheurer R.W., Vos T., Scott J.G. The epidemiology and global burden of autism spectrum disorders. Psychol Med, 2015;45(3):601-13

10. Mazurkiewicz-Bełdzińska M. Epidemiologia padaczki. W: Szczudlik A., Jędrzejczak J., Mazurkiewicz-Bełdzińska M. red., Padaczka Tom I. wyd.1., Poznań 2012; Termedia: s. 24-25.

11. Canitano R. Epilepsy in Autism Spectrum Disorders. Eur Child Adolesc Psychiatry, 2007;16: 61-66.

12. Tuchman R., Cuccaro M., Alessandri M. Autism and epilepsy: Historical perspective. Brain Dev, 2010;32: 709-718.

13. Amiet C., Gourfinkel-An I., Bouzamondo A., Tordjman S, Baulac M, Lechat $\mathrm{P}$, et al. Epilepsy in autism is associated with intellectual disability and gender: Evidence from a meta-analysis. Biol Psychiatry, 2008;64:577-82.

14. Simonoff E., Pickles A., Charman T., Chandler S., Loucas T., \& Baird G. Psychiatric disorders in children with autism spectrum disorders: prevalence, comorbidity, and associated factors in a population derived sample. J Am Acad Child Adolesc Psychiatry, 2008;47:921-929.

15. Witwer A.N., Lecavalier L. Validity of Comorbid Psychiatric Disorders in Youngsters with Autism Spectrum Disorders. J Dev Phys Disabil, 2010;22: 367-380.

16. Salazar F., Baird G., Chandler S., Tseng E., O'sullivan T., Howlin P. et al. Co-occurring psychiatric disorders in preschool and elementary school-aged children with autism spectrum disorder . J Autism Dev Disord, 2015; 45: 2283-2294

17. Robinson S.J. Childhood epilepsy and autism spectrum disorders: psychiatric problems, phenotypic expression, and anticonvulsants. Neuropsychol Rev, 2012;22:271-9.

18. Grabowska-Grzyb A. Zaburzenia psychiczne w padaczce. W: Szczudlik A., Jędrzejczak J., Mazurkiewicz-Bełdzińska M. red., Padaczka Tom I. wyd.1., Poznań 2012; Termedia: s. 53-59.

19. Torta R., Keller R. Behavioral, psychotic and anxiety disorders in epilepsy: etiology, clinical features and therapeutic implications. Epilepsia, 1999; 40 (10): 2-20.

20. Su C.C., Chi M.H., Lin S.H., Yang Y.K. Bidirectional association between autism spectrum disorder and epilepsy in child and adolescent patients: a population-based cohort study. Eur Child Adolesc Psychiatry, 2016; 25(9):979-87

21. Besag F.M. Current controversies in the relationships between autism and epilepsy. Epilepsy Behav, 2015;47:143-146.

22. Turk J., Bax M., Williams C., Amin P., Eriksson M., Gillberg C. Autism spectrum disorder in children with and without epilepsy: impact on social functioning and communication. Acta Paediatr, 2009; 98:675-681.

23. Smith K.R.M., Matson J.L. Psychopathology: differences among adults with intellectually disabled, comorbid autism spectrum disorders and epilepsy. Res Dev Disabil, 2010; 31:743-749.

24. Stranga J. ,Kenworthy L., Daniolos P., Case L., Wills M., Martin A., et al. Depression and anxiety symptoms in children and adolescents with autism spectrum disorders without intellectual disability. Res Autism Spectr Disord, 2012; 6: 406-412.

25. Bitsika V., Sharpley C.F., Andronicos N. M., Agnew L.L. Prevalence, structure and correlates of anxiety-depression in boys with an autism spectrum disorder. Res Dev Disabil, 2016; 49: 302-311

26. Mouridsen S.E., Rich B., Isager T. A longitudinal study of epilepsy and other central nervous system diseases in individuals with and without a history of infantile autism. Brain Dev, 2011; 33: 361-366.

27. Saemundsen E., Ludvigsson P., Hilmarsdottir I., Rafnsson V. Autism spectrum disorders in children with seizures in the first year of life - a population-based study. Epilepsia, 2007; 48: 1724- 30.

28. Bolton P.F., Carcani-Rathwell I., Hutton J., Goode S., Howlin P., et al. Epilepsy in autism: features and correlates. Br J Psychiatry, 2011;198: 289-294 
29. Kreiser N.L., White S.W. ASD Traits and Co-occurring Psychopathology: The Moderating Role of Gender. J Autism Dev Disord, 2015; 45 (12): 3932-8

30. Rieske R.D., Matson J.L., Beighley J.S., Cervantes P.E., Goldin R.L., Jang J. Comorbid psychopathology rates in children diagnosed with autism spectrum disorders according to the DSM-IV-TR and the proposed DSM-5. Dev Neurorehabil, 2015; 18(4): 218-223.

31. Mula M. Epilepsy: bidirectional link between epilepsy and psychiatric disorders. Nat Rev Neurol, 2012;8:252-3.

32. Bilgic A., Yilmaz S., Tiras S., Deda G., Kilic E.Z. Depression and anxiety symptom severity in a group of children with epilepsy and related factors. Turk Psikiyatri Derg, 2006;17:165-72.

33. Guinchat V., Cravero C., Diaz L., Perisse D., Xavier J., Amiet C., Consoli A. Acute behavioral crises in psychiatric in patients with autism spectrum disorder (ASD): Recognition of concomitant medical or non-ASD psychiatric conditions predicts enhanced improvement. Res Dev Disabil, 2015;38: 242-255.

\section{Correspondence address}

Żaneta Brudkowska

Zakład Neuropsychiatrii Klinicznej Katedry Psychiatrii,

Uniwersytet Medyczny w Lublinie,

ul. Głuska 2,

20-439 Lublin;

Tel. 695792896

e-mail: brudkowskaz@gmail.com

Otrzymano: 07.08.2016

Zrecenzowano: 27.09.2016

Przyjęto do druku: 28.09.2016 